\title{
A study of long-term potentiation in transgenic mice over-expressing mutant forms of both amyloid precursor protein and presenilin-1
}

\author{
Stephen M Fitzjohn*1, Frederick Kuenzi1,2, Robin A Morton1,2, Thomas W Rosah|2,3, Huw Lewis², David Smith2, \\ Guy R Seabrook2,4 and Graham L Collingridge ${ }^{1}$
}

\begin{abstract}
Synaptic transmission and long-term potentiation (LTP) in the CA1 region of hippocampal slices have been studied during ageing of a double transgenic mouse strain relevant to early-onset familial Alzheimer's disease (AD). This strain, which over-expresses both the 695 amino acid isoform of human amyloid precursor protein (APP) with K670N and M671L mutations and presenilin 1 with the A246E mutation, has accelerated amyloidosis and plaque formation. There was a decrease in synaptic transmission in both wildtype and transgenic mice between 2 and 9 months of age. However, preparing slices from 14 month old animals in kynurenic acid (1 mM) counteracted this age-related deficit. Basal transmission and paired-pulse facilitation was similar between the two groups at all ages (2, 6, 9 and 14 months) tested. Similarly, at all ages LTP, induced either by theta burst stimulation or by multiple tetani, was normal. These data show that a prolonged, substantially elevated level of $A \beta$ are not sufficient to cause deficits in the induction or expression of LTP in the CA1 hippocampal region.
\end{abstract}

\section{Background}

Three loci have been identified that account for nearly all the familial Alzheimer's disease (AD) cases. Mutations in the amyloid precursor protein (APP) gene account for around 2-3\% percent of familial AD cases and mutations in presenilins 1 and 2 (PS1 and PS2) have been linked to $70-80 \%$ of early onset AD [1-3]. The mutations associated with early onset familial AD in a Swedish family, where the 695 amino acid APP protein contains the two mutations K670N and M671L ( $\mathrm{APP}_{695} \mathrm{SWE}$ mutation), affect cleavage of APP at the $\beta$-secretase site [4]. Subsequent cleavage of APP at the intramembranous $\gamma$-secretase site results in the formation of A $\beta$. PS1 is intimately associated with the cleavage of APP at the $\gamma$-secretase site and familial AD mutations in PS1, such as the A246E mutation occurring in transmembrane domain 6 of the presenilin protein $[5,6]$, alter the efficiency of cleavage of APP and accelerate the production of $A \beta[3,6-8]$.

\footnotetext{
* Correspondence: stephen.fitzjohn@bris.ac.uk

1 MRC Centre for Synaptic Plasticity, Department of Anatomy, University of Bristol, University Walk, Bristol, BS8 1TD, UK

Full list of author information is available at the end of the article
}

Mice expressing the human form of the $\mathrm{APP}_{695} \mathrm{SWE}$ mutation develop certain AD-like symptoms, such as increased $A \beta$ deposits and plaques, increased glial cell number, and deficits in spatial memory learning tasks [912]. Physiological studies have focused on the hippocampus, a region affected by $\mathrm{AD}$, and have studied, in particular, long-term potentiation (LTP) as a candidate synaptic mechanism involved in learning and memory [13]. However, the findings have been controversial. Thus, one study reported normal synaptic transmission but impaired LTP in the $\mathrm{APP}_{695} \mathrm{SWE}$ mutant [12] whilst in other studies synaptic transmission was impaired but LTP was normal in the mutant $[14,15]$. In contrast, mice expressing the PS1 $1_{\mathrm{A} 246 \mathrm{E}}$ mutation showed enhanced LTP [16], along with increased production of $A \beta(42)$, the longer form of $A \beta$ associated with plaque formation [17].

Mice expressing mutations in both APP and PS1 exhibit accelerated $A \beta$ production compared to those carrying mutations in only APP or PS1 [18]. Studies using double transgenic (DbTg) mice expressing both the $\mathrm{APP}_{695} \mathrm{SWE}$ mutations in APP and either the PS1 $1_{\mathrm{M} 146 \mathrm{~L}}[19]$ or PS1 $1_{\mathrm{P} 264 \mathrm{~L}}$ [20] mutation showed reduced hippocampal LTP at a younger age than basal synaptic transmission was com- 
promised. However, a recent study found no alteration in hippocampal synaptic transmission or plasticity in mice overexpressing the $\mathrm{APP}_{695} \mathrm{SWE}$ and $\mathrm{PS}_{\triangle \mathrm{E} 9}$ mutations, even though the mice showed deficits in spatial learning [21]. Another DbTg strain of mouse which over-expresses both the 695 amino acid isoform of human amyloid precursor protein (APP) with K670N and M671L mutations $\left(\mathrm{APP}_{695} \mathrm{SWE}\right.$ mice) and the A246E mutation in PS1 $\left(\mathrm{PS}_{\mathrm{A} 246 \mathrm{E}}\right)$ has much more aggressive amyloidosis and plaque deposition than the $\mathrm{APP}_{695} \mathrm{SWE}$ mice [17]. Given the relevance of these mouse models to human disease but the conflicting findings of the effect of double mutations on synaptic transmission and plasticity in the hippocampus, we report here an analysis of these DbTg animals.

\section{Methods}

\section{Transgenic mice}

The generation of the $\mathrm{APP}_{695} \mathrm{SWE}$ transgenic mice used in this study has been described previously $[9,22]$. $\mathrm{APP}_{695} \mathrm{SWE}$ transgenic mice were originally in a hybrid 87.5\% C57BL6 x 12.5\% SJL genetic background and were subsequently backcrossed to C57BL6 x SJL F1 mice over several generations. $\mathrm{APP}_{695} \mathrm{SWE}$ transgenic mice in a background closer to 50\% C57BL6-50\% SJL were then crossed with the $\mathrm{PS} 1_{\mathrm{A} 246 \mathrm{E}}$ transgenic line overexpressing the familial AD PS1 ${ }_{\mathrm{A} 246 \mathrm{E}}$ mutation of human PS1 [23] to generate the DbTg line $\left(\mathrm{APP}_{695} \mathrm{SWE} x \mathrm{PS}_{\mathrm{A} 246 \mathrm{E}}\right.$; Lewis et al, 2004). All animals used in this study were from the N4 generation. All procedures were carried out in accordance with The UK Animals (Scientific Procedures) Act 1986.

Four age groups were studied: 2 months (i.e., between 2 and 3 months of age), 6 (6-7), 9 (9-10) and 14 (14 -15) months of age. Mice older than 15 months were not studied because of their high mortality and ethical considerations. All mice in this study were either heterozygous for both the $\mathrm{APP}_{695} \mathrm{SWE}$ and $\mathrm{PS}_{\mathrm{A} 246 \mathrm{E}}$ transgene (DbTg) or their wildtype (Wt) littermates. Animals were genotyped using PCR based methods for detection of the $\mathrm{APP}_{695} \mathrm{SWE}$ transgene $[9,14,22]$, the $\mathrm{PS}_{\mathrm{A} 246 \mathrm{E}}$ transgene [23] and for the $r d$ (retinal degeneration) mutation [24]. $R d$ homozygous mice were excluded from this study as a precaution, since it has been suggested that this mutation may indirectly affect neuronal number within the hippocampus [25]. All experiments and analyses were performed with the experimenters blind as to the genotype of the animal.

\section{Quantification of $A \beta$ levels by HTRF}

Levels of $A \beta$ were determined by homogenous timeresolved fluorescence (HTRF) immunoassay as described previously [26]. Amyloid was extracted from the contral- ateral hemispheres by homogenisation in 10 volumes of 5 $\mathrm{M}$ GnHCl, $50 \mathrm{mM}$ HEPES (pH 7.3), 5 mM EDTA plus 1x protease inhibitor cocktail (Complete ${ }^{\mathrm{TM}}$, obtained from Roche Diagnostics). Following $3 \mathrm{~h}$ rotation at room temperature, the homogenate was diluted ten-fold into icecold 25 mM HEPES (pH 7.3), 1 mM EDTA, 0.1\% BSA plus $1 \mathrm{x}$ protease inhibitor cocktail and centrifuged $\left(16,000 \mathrm{~g}, 20 \mathrm{~min}, 4^{\circ} \mathrm{C}\right)$. Aliquots of the supernatant were stored at $-20^{\circ} \mathrm{C}$. The levels of amyloid peptides $\mathrm{A} \beta(40)$ and $A \beta(42)$ were then detected by HTRF. All peptides (of $>$ 95\% purity; California Peptide Research Inc., California, U.S.A.) were frozen at $100 \mu \mathrm{M}$ in $100 \%$ DMSO and serially diluted in buffer whose composition reflects that of the extracted samples ( 1 part $\mathrm{GnHCl}$ extraction buffer: 9 parts dilution buffer, as above). The HTRF signal was generated as a result of non-radiative transfer from europium cryptate-labelled $A \beta$ (40)- or $A \beta$ (42)-specific antibodies (G2-10 and G2-11 respectively; licensed from the University of Heidelberg; labelled at CIS bio international, Marcoule, France) to streptavidin-conjugated APC (Prozyme). The latter was brought into the complex by interaction with biotinylated antibody 4G8 (Senetek plc, Missouri, U.S.A.), which is specific for residues 17-24 of A $\beta$. Final reagent concentrations in a typical 96-well plate assay were: G2-10K (0.75 nM) or G2-11K (0.6 nM), 4G8 +/- biotin (1.0 nM), SA-XL665 (2.0 nM), KF (0.1-0.2 M). $50 \mu \mathrm{l}$ of sample or synthetic peptide standard were assayed and a total volume of $200 \mu \mathrm{l} /$ well was made up with dilution buffer. Blank values were determined by the use of non-biotinylated $4 \mathrm{G} 8$ antibody. The reaction mixture was left at $4^{\circ} \mathrm{C}$ for $20 \mathrm{~h}$, and then read on the Discovery $^{\mathrm{TM}}$ HTRF microplate analyser, providing simultaneous measurement at $665 \mathrm{~nm}$ (XL665 fluorescence) and 620 $\mathrm{nm}$ (EuK fluorescence). The $\Delta \mathrm{R}$ ratio [= Ratio (sample) Ratio (blank)] was used to extrapolate the amyloid concentrations of the brain extracts from the synthetic peptide standard curves.

\section{Histology}

Histology to demonstrate plaque deposition was performed as described previously (Lewis et al, 2004). Briefly, $6 \mu \mathrm{m}$ sagittal hippocampal slices were prepared and monoclonal anti-human $\beta$-amyloid (clone 6F3D) (DAKO, UK) was used to demonstrate amyloid plaques whilst polyclonal anti-GFAP (glial fibrillary acidic protein: DAKO) used to label reactive astrocytes. Endogenous peroxidase activity was blocked in $0.3 \% \mathrm{H}_{2} \mathrm{O}_{2}$ in 0.1 $\mathrm{M} \mathrm{pH} \mathrm{7.4} \mathrm{phosphate} \mathrm{buffered} \mathrm{saline} \mathrm{(PBS)} \mathrm{for} 30 \mathrm{~min}$; non-specific binding was blocked by incubation with $5 \%$ normal horse serum (5\% NHS) (Vector Labs, UK) in PBS for $1 \mathrm{~h}$. Mouse anti- $\beta$-amyloid was applied (1:100 in 5\% NHS) overnight at $4^{\circ} \mathrm{C}$. Biotinylated anti-mouse IgG (Vector Labs) was applied for $30 \mathrm{~min}$, followed by $\mathrm{ABC}$ reagent (Vector Elite, Vector Labs) for $30 \mathrm{~min}$. DAB 
(Menarini, UK) was used as the chromogenic substrate. Peroxidase activity was quenched in $0.3 \% \mathrm{H}_{2} \mathrm{O}_{2}$ /PBS and sections further incubated in polyclonal anti-GFAP (1:1000 in $5 \%$ normal goat serum) overnight at $4{ }^{\circ} \mathrm{C}$. Visualisation was achieved by incubation in biotinylated antirabbit IgG followed by ABC reagent (Vector Elite, Vector Labs).

\section{Electrophysiology}

Recordings were made form $350 \mu \mathrm{m}$ thick hippocampal slices prepared from 2, 6, 9 and 14 month old DbTg and Wt mice. Animals were killed by decapitation, as licensed under the UK Animals (Scientific Procedures) Act 1986, and the brains rapidly removed in ice-cold artificial cerebrospinal fluid (aCSF). The composition of this aCSF was, in $\mathrm{mM}: \mathrm{NaCl}, 126 ; \mathrm{NaH}_{2} \mathrm{PO}_{4}, 1.2 ; \mathrm{MgCl}_{2}, 1.3 ; \mathrm{CaCl}_{2}$, 2.4; $\mathrm{KCl}, 2.5 ; \mathrm{NaHCO}_{3}$, 26; glucose, 10. Brains were cut along the midline and parasagittal whole brain slices prepared from one hemisphere (randomly chosen) using a Vibratome. The hippocampus was then dissected out of these slices. The contralateral hemisphere was used for histology or determination of $A \beta$ levels. Slices were allowed to recover for at least $1 \mathrm{~h}$ at room temperature before being transferred to a submerged recording chamber perfused with aCSF at $2 \mathrm{ml} . \mathrm{min}^{-1}$ and maintained at $33^{\circ} \mathrm{C}$. Kynurenic acid $(1 \mathrm{mM})$ was included in the aCSF used for preparing slices from the 14 month old animals. Slices were then transferred to non-kynurenic acid containing aCSF approximately $30 \mathrm{~min}$ after dissection and allowed to recover for a further $30 \mathrm{~min}$.

Field excitatory postsynaptic potentials (fEPSPs) were recorded from stratum radiatum of area CA1 and Schaffer collateral-commissural fibres were stimulated using a bipolar nickel-chromium electrode. The initial slope of the negative-going phase of the fEPSP was used as a measure of synaptic efficacy. Recordings were made using a SPIKE 2 script running on a CED1401plus interface (Cambridge Electronic Design). Stimulus-response curves were constructed by using stimulus intensities from 0 to $45 \mathrm{~V}$ in increments of $5 \mathrm{~V}$. Responses were subsequently set to a level that gave a slope value of approximately $20 \%$ of the maximum obtained. Baseline responses were obtained every $30 \mathrm{~s}$. Paired-pulse facilitation (PPF) was assessed using a succession of paired-pulses using inter-pulse intervals of 25, 50, 100, 200 and $300 \mathrm{~ms}$. A further $30 \mathrm{~min}$ baseline period was obtained before attempting to induce LTP.

LTP was induced by delivery of a theta burst stimulation paradigm (TBS), which comprised 10 bursts, at an interburst frequency of $5 \mathrm{~Hz}$ and an intraburst frequency of $100 \mathrm{~Hz}$, each burst consisting of 4 stimuli delivered at test stimulus intensity. In some experiments, LTP was induced using a stronger stimulation whereby a repetitive tetanic stimulus was applied (100 stimuli at $100 \mathrm{~Hz}$ at test intensity repeated 4 times at $5 \mathrm{~min}$ intervals). All data are presented as mean \pm s.e.mean. $n$ values are given as $[x(y)]$ where $\mathrm{x}=$ number of slices and $\mathrm{y}=$ number of animals. Data were log transformed and analysed using a one-way ANOVA with repeated measures (BMDP statistical package, release 7). Linear regression of fEPSP slope vs fibre volley amplitude was done with Microsoft Excel 97 Analysis Toolpack.

\section{Results}

\section{$A \beta$ levels and amyloid plaque deposition}

Expression of the $\mathrm{APP}_{695} \mathrm{SWE} \times \mathrm{PS}_{\mathrm{A} 246 \mathrm{E}}$ transgenes produced a dramatic increase in both short $(\mathrm{A} \beta(40))$ and long $(A \beta(42))$ forms of the $A \beta$ peptide (Fig. 1). This elevation in $A \beta$ levels occurred several months earlier than in the single $\mathrm{APP}_{695} \mathrm{SWE}$ transgenic $[14,26]$. At 9 months, the $A \beta$ load was significantly greater than in Wt brains; levels of $A \beta(40)$ were $3.0 \pm 0.5$ compared with $0.03 \pm 0.02$ $\mathrm{nmol} / \mathrm{g}$ wet weight tissue and levels of $A \beta(42)$ were $1.6 \pm$ 0.4 compared to $0.01 \pm 0.009 \mathrm{nmol} / \mathrm{g}$ wet weight tissue, in $\mathrm{DbTg}$ and Wt mice, respectively. At 14 months the levels of $A \beta(40)$ and $A \beta(42)$ increased to $10.8 \pm 2.2$ and $5.6 \pm 1.4$ $\mathrm{nmol} / \mathrm{g}$ wet weight tissue in DbTg mice, compared to 0.01

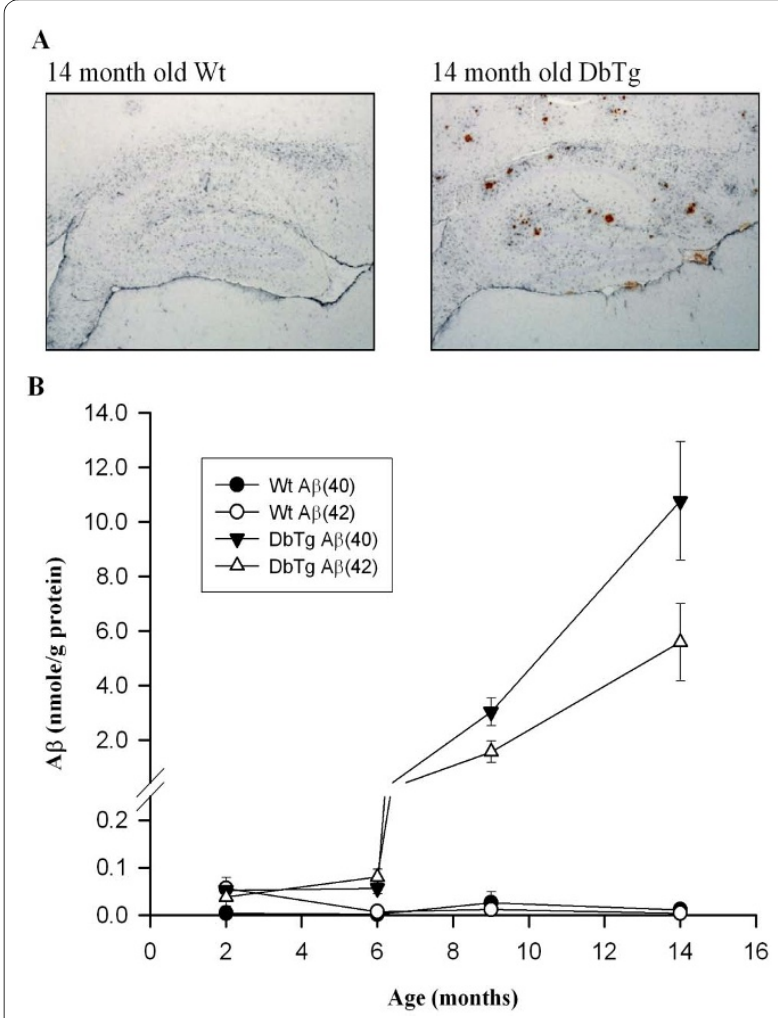

Figure 1 Plaques and elevated levels of $A \beta(40)$ and $A \beta(42)$ in DbTg (Tg) mice. (A) Example hippocampal slices from 14 month old animals, illustrating plaque formation in the Dbtg mice (brown) accompanied by astrocytosis (black). (B) Pooled data showing levels of $A \beta(40)$ and $A \beta(42)$ in Wt and DbTg mice. 
\pm 0.01 and $0.004 \pm 0.003 \mathrm{nmol} / \mathrm{g}$ wet weight tissue in Wt mice (Fig. 1B). In addition, compared to the single transgenic $\mathrm{APP}_{695} \mathrm{SWE}$ mouse, the $\mathrm{A} \beta(42) / \mathrm{A} \beta(40)$ ratio is enhanced throughout the life of the animal $[14,26]$. Plaques were also evident in aged DbTg mice throughout the hippocampus, but were not evident in Wt animals (Fig. 1A; [26]).

\section{Basal synaptic transmission}

Synaptic transmission was quantified over a wide range of stimulus intensities and was analysed in terms of fEPSP slope versus stimulus intensity (Fig. 2) and fEPSP slope versus fibre volley (FV) amplitude (Fig. 3). Using both methods of analysis there was a pronounced, age-dependent decline in synaptic transmission in slices obtained from both Wt and DbTg mice of between 2 and 9 months of age. Indeed, it was difficult to obtain viable synaptic responses from slices prepared form both $\mathrm{Wt}$ and $\mathrm{DbTg}$

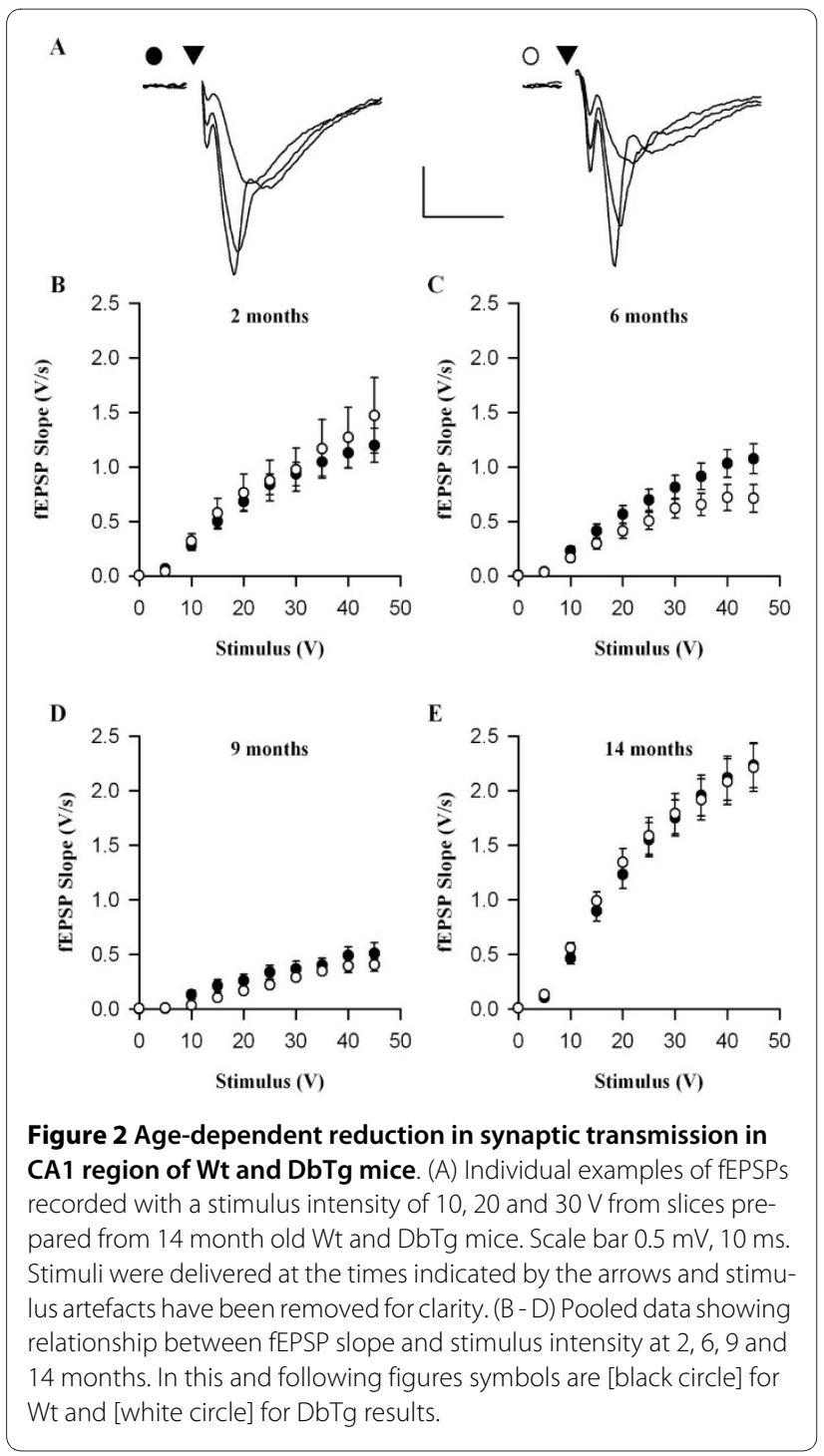

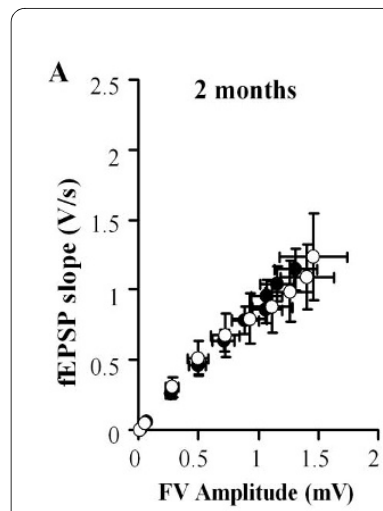
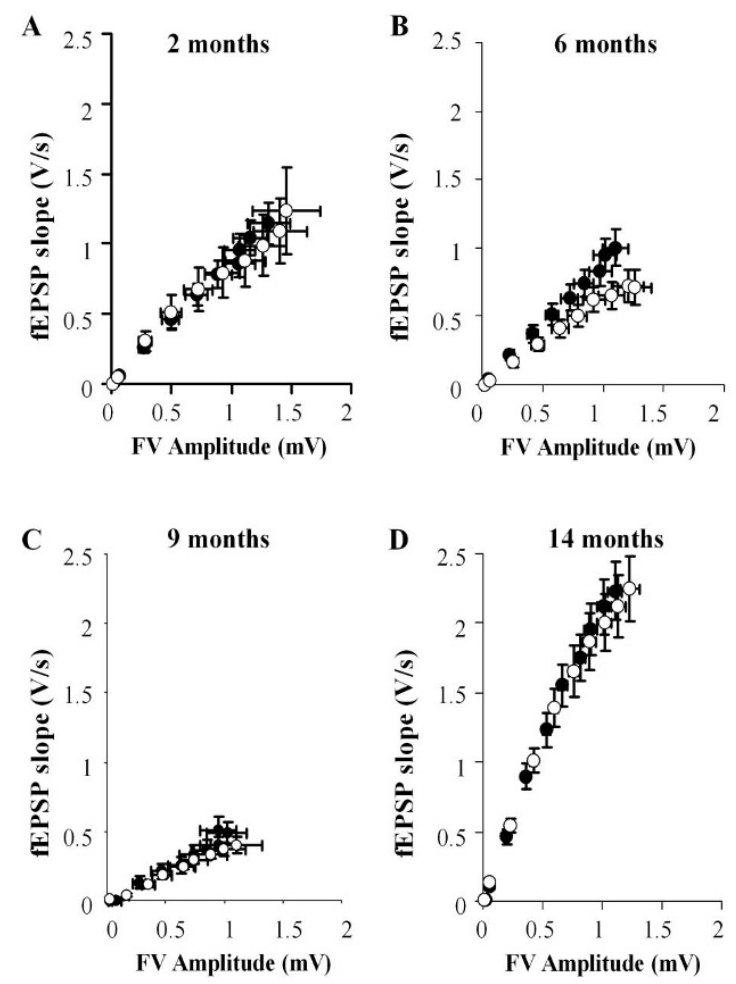

Figure 3 Analysis of fibre volley (FV) amplitude and fEPSP slope Pooled data from 2, 6, 9 and 14 month old Wt and DbTg animals respectively grouped by stimulus intensity ([black circle] Wt, [white circle] DbTg).

animals in the 9 month age group and many failed to produce a fEPSP. For this reason we performed the dissections for the 14 month age group in the presence of kynurenic acid, since this treatment has been shown to greatly improve slice viability of some transgenic mouse strains $[12,14]$. This treatment resulted in considerably improved synaptic viability (Figs $2 \& 3$ ).

The input-output curves were generally similar for both genotypes, at all ages studied (Figs 2 \&3). For example, in 14 month old mice the slope of the relationship between

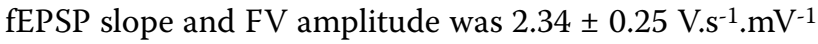
[47 (11)] in Wt animals and $2.42 \pm 0.31 \mathrm{~V} \cdot \mathrm{s}^{-1} \cdot \mathrm{mV}^{-1}[43$ (13)] in DbTg mice ( $>$ > 0.05). The maximum obtained fEPSPs were also similar in the two groups. For example, in 14 month old mice the fEPSP evoked by $45 \mathrm{~V}$ stimulation was $2.32 \pm 0.21{\mathrm{~V} . \mathrm{s}^{-1}}\left[47\right.$ (11)] and $2.21 \pm 0.22{\mathrm{~V} . \mathrm{s}^{-1}}^{-1}$ [43 (13)] ( $\mathrm{p}>0.05$ ) in Wt and DbTg mice, respectively.

\section{Paired-pulse facilitation}

In all age groups, there was no difference in the level of PPF (slope of second response/slope of first response) between $\mathrm{DbTg}$ and Wt mice. For example, at an interstimulus interval (ISI) of $50 \mathrm{~ms}$ the PPF ratios for Wt and DbTg mice were, respectively, at 2 months: $1.86 \pm 0.05$ [30 
(13)] and $1.99 \pm 0.13$ [20 (10)]; 6 months: $1.93 \pm 0.07$ [24

(8)] and $1.80 \pm 0.15$ [15 (7)]; 9 months: $1.81 \pm 0.10$ [28

(10)] and $1.75 \pm 0.09$ [19 (8)] and 14 months: $1.72 \pm 0.03$

[28 (8)] and $1.77 \pm 0.04$ [24 (6)] (in all cases, $\mathrm{p}>0.05$ ).

There was also no age-related change in the level of PPF in either Wt or DbTg animals ( $p>0.05$ at all stimulus intervals used). PPF data over a range of inter-pulse intervals for the 2 and 14 month age group are presented in Fig. 4.

\section{Long-term potentiation}

A theta burst stimulus (total of 40 stimuli) induced robust LTP in the CA1 region in all age groups. The level of LTP was similar in both genotypes across all ages, quantified for up to $60 \mathrm{~min}$ following theta burst stimulation (Fig. 5A-D; $p>0.05$ at all age groups). For example, the level of LTP observed 60 minutes after theta burst stimulation in Wt and DbTg animals was, at 2 months: $156 \pm 9 \%$ [9 (5)] and $171 \pm 12 \%$ [8 (6)]; 6 months: $205 \pm 17 \%$ [18 (9)] and $216 \pm 32 \%$ [13 (7)]; 9 months: $171 \pm 9$ [15 (8)] and $211 \pm$ $22 \%$ [8 (4)]; 14 months: $186 \pm 10 \%$ [23 (13)] and $178 \pm$ $15 \%$ [16 (9)]. There was no age-related change in the level of LTP seen following theta burst stimulation for either Wt of DbTg mice. In the 14 month age group, a subset of slices was followed for over $3 \mathrm{~h}$ following theta burst stimulation. There was no difference between genotypes, the level of LTP seen 3.5 hours post-theta burst stimulation in Wt and DbTg animals was $196 \pm 28 \%$ [9 (5)] and $183 \pm 20 \%[9(5)](p>0.05$; Fig. 5E).

A

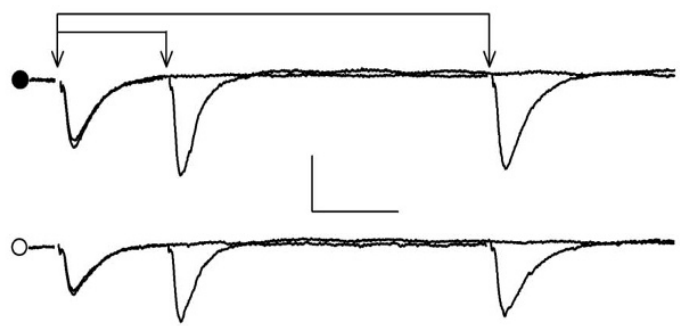

B

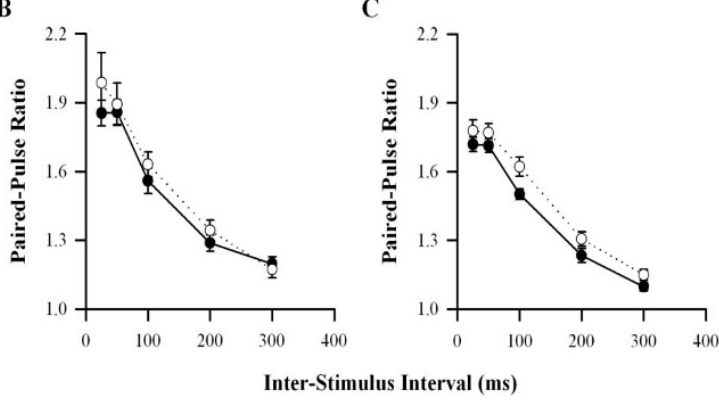

Figure 4 PPF is normal in DbTg mice. (A) Example traces taken from 14 month old Wt (black circle) and DbTg (white circle) animals showing PPF at ISIs of 25 and $100 \mathrm{~ms}$. Scale bar $0.5 \mathrm{mV}, 20 \mathrm{~ms}$. (B, C) Pooled data for 2 (B) and 14 (C) month-old animals.

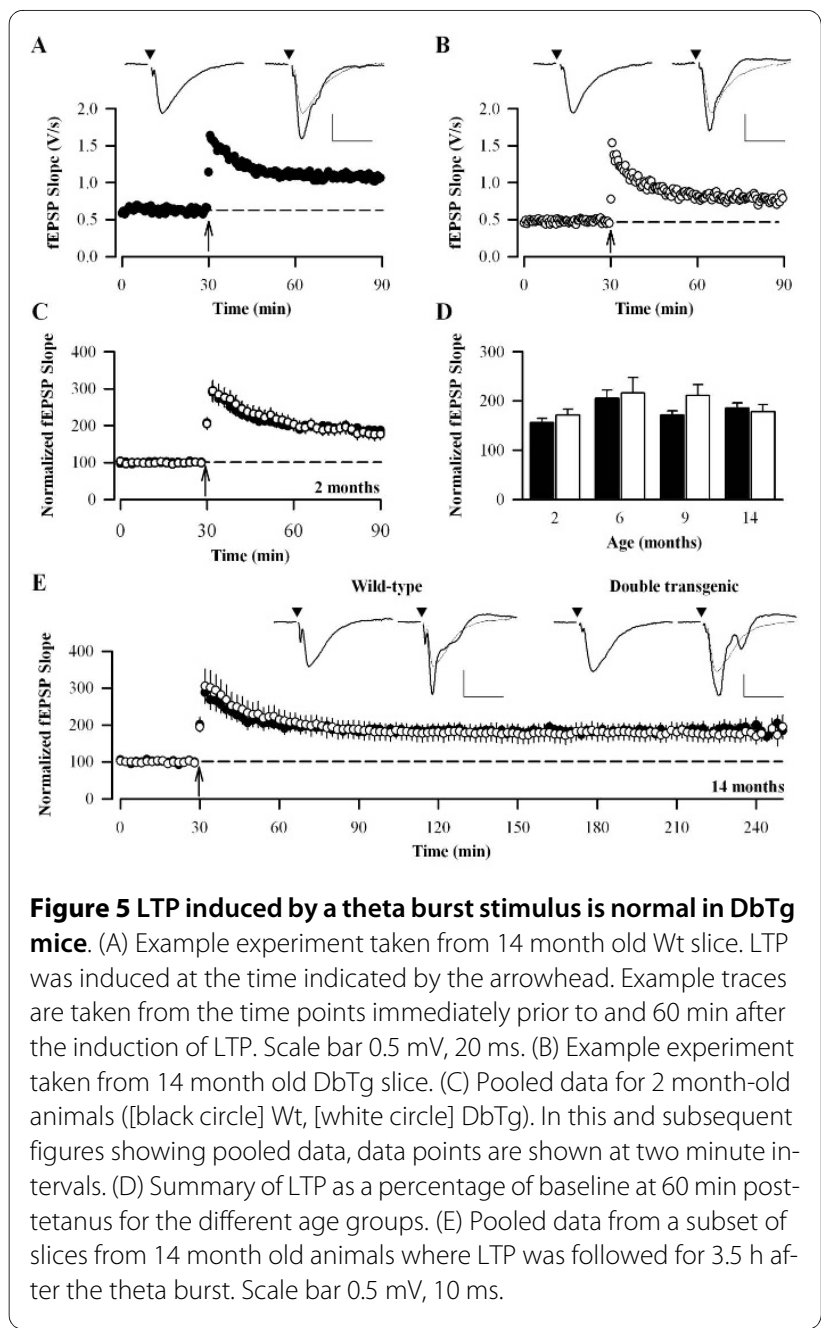

In a second series of experiments, a stronger induction protocol was delivered (total of 400 stimuli) and LTP again followed for over $3 \mathrm{~h}$ (Fig. 6). The levels of LTP were similar for each genotype at all ages ( $p>0.05$ at $3.5 \mathrm{~h}$ ), thus at 3.5 hours post-LTP induction the level of LTP in Wt and DbTg animals was, at 2 months: $189 \pm 18 \%$ [10 (5)] and $188 \pm 28$ [7 (3)]; 6 months $151 \pm 17 \%$ [11 (9)] and $139 \pm 23 \%$ [8 (5)]; 9 months: $177 \pm 26 \%$ [11 (6)] and $159 \pm$ $23 \%$ [9 (5)]; 14 months: $203 \pm 12 \%$ [20 (9)] and $168 \pm 14 \%$ [16 (8)]. Again, there was no age-related change in the level of LTP induced by this strong induction protocol for either Wt or DbTg animals.

\section{Discussion}

In DbTg mice over-expressing the human familial $\mathrm{AD}$ transgenes $\mathrm{APP}_{695} \mathrm{SWE}$ and $\mathrm{PS}_{\mathrm{A} 246 \mathrm{E}}$, $\mathrm{A} \beta$ peptides accumulate in an accelerated age-dependent manner with an early enhancement of the $A \beta(42) / A \beta(40)$ ratio (see also [26]). Accelerated production of $A \beta$ has also been reported in different mouse strains expressing double mutations of APP and PS1 (reviewed in [18]). However, 


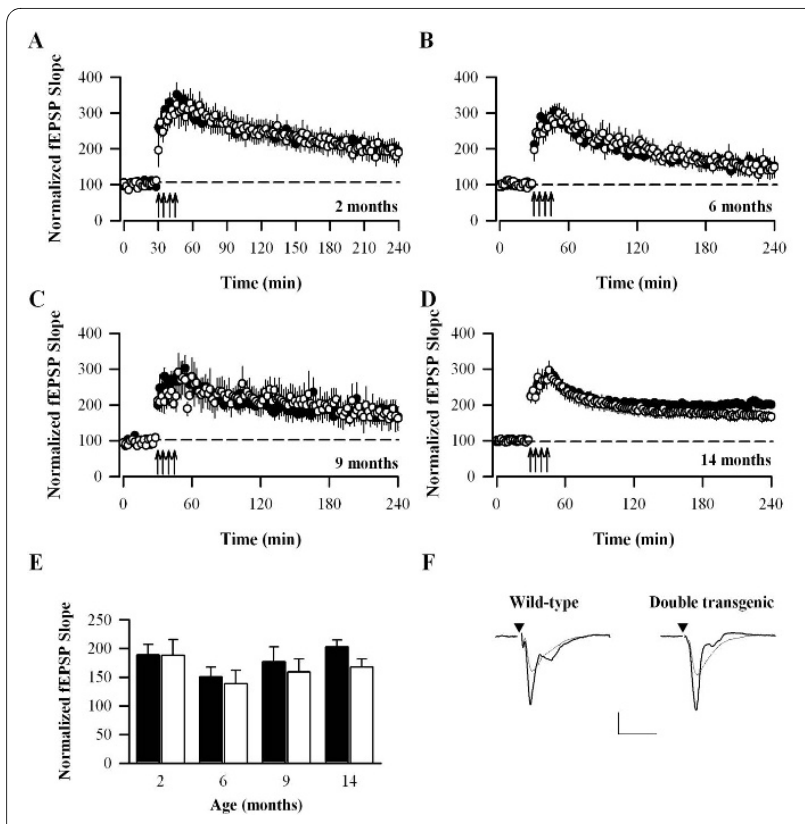

Figure 6 LTP induced by repeated tetani is normal in DbTg mice. (A-C) Pooled data for slices from 2, 6 and 9 month old animals ([black circle] Wt, [white circle] DbTg). (D) Summary of the LTP as a percentage of baseline at 3.5 hours after the last tetanus for the different age groups. (E) Pooled data for slices from 14 month old animals. Traces are taken from the time points immediately prior to induction of LTP and $3.5 \mathrm{~h}$ after the last tetanus. Scale bar $0.5 \mathrm{mV}, 5 \mathrm{~ms}$. LTP was induced by the delivery of four tetanic stimuli separated by $5 \mathrm{~min}$ at the times indicated by the arrowheads.

there has been little work carried out into studying synaptic function and plasticity in these multiple transgenic mice lines. We find that normal LTP in the CA1 region can be recorded over a wide age range and that there is little, if any, difference between the $\mathrm{DbTg}$ and the $\mathrm{Wt}$ mice.

\section{Effects on basal synaptic transmission}

Consistent with our earlier report on the $\mathrm{APP}_{695} \mathrm{SWE}$ single transgenic mouse [14] we found that there was an agedependent reduction in fEPSPs evoked by a fixed stimulus intensity over a wide range. The deficit was clearly present when synaptic transmission was compared with the amplitude of the presynaptic fibre volley and therefore reflects a reduction in the input-output relationship. This age-related decrease in basal synaptic transmission was similar in both Wt and DbTg mice, with little if any difference between the two groups at each age point. Similarly, Volianskis et al. [21] recently reported a similar age-related decrease in basal transmission in mice overexpressing $\mathrm{APP}_{695} \mathrm{SWE}$ and $\mathrm{PS}_{\triangle \mathrm{E} 9}$ transgenes, which was similar in both groups of animals. Consistent with previous studies $[12,14]$, the reduction in synaptic transmission was prevented by blockade of ionotropic glutamate receptors with kynurenic acid during slice preparation, suggesting that it was due to increased susceptibility to excitotoxicity, which may be a characteristic of the background mouse strain on which the transgenes are expressed. Interestingly, hippocampal cultures prepared from double transgenic animals $\left(\mathrm{APP}_{\mathrm{SWE}}\right.$ and $\left.\mathrm{PS}_{\mathrm{L} 166 \mathrm{P}}\right)$ show a reduction in excitatory synapses compared to cultures from wildtype or $\mathrm{APP}_{\mathrm{SWE}}$ mice, suggesting that the inclusion of the PS1 transgene may have an additional effect on glutamatergic synapse formation under some conditions [27].

Here we have shown that, even at 14 month of age, there is no deficit in basal transmission in DbTg compared to Wt animals. This is despite the fact that $\mathrm{A} \beta$ levels are greatly enhanced in these animals and plaques are also evident in the hippocampus and other brain regions (see [26]). Thus it appears that the increased production of $A \beta$ in these mice does not impair basal synaptic function.

\section{Effects on LTP}

Previous studies using transgenic mouse modes of Alzheimer's disease have resulted in little consensus on the effects of mutations in APP and PS1 with respect to LTP. For example, a reduction of LTP has been reported in mice that over-express either the London (V642I; [28] or Swedish $\left(\mathrm{APP}_{695} \mathrm{SWE}\right.$; $[12,29]$ mutations in APP. In contrast, no impairment was observed in single transgenic mice that over-express the V717F mutant form of APP ( $\mathrm{APP}_{\text {Ind; }}$ [30-32]) and in studies using the $\mathrm{APP}_{695} \mathrm{SWE}$ mutation [14,15]. Both the $\triangle \mathrm{E} 9$ [33] and A246E [16] mutations in PS1 have previously been shown to lead to enhanced LTP expression. Mice under-expressing PS1 have displayed reduced levels of LTP in one study [34] but normal LTP in another [35].

Few studies to date have been conducted using mice expressing double mutations in APP and PS1. One previous study reported an increased rate of decay in dentate gyrus LTP in vivo in 17-18 month old mice expressing the $\mathrm{APP}_{695} \mathrm{SWE}$ and $\mathrm{PS}_{\mathrm{A} 246 \mathrm{E}}$, mutations [36], but normal CA1 LTP in vitro at this age. Two studies have found impairments in hippocampal LTP [37] and hippocampaldependent learning $[37,38]$ in both aged wildtype and transgenic mice overexpressing mutated APP and PS1, suggesting that deficits were independent of $A \beta$ or plaque load. Although impairments in CA1 LTP have been observed in mice expressing mutations in both APP and PS1 in some studies [19], [39], a recent study using mice expressing both $\mathrm{APP}_{695} \mathrm{SWE}$ and $\mathrm{PS}_{\triangle \mathrm{E} 9}$ found no deficit in hippocampal LTP in vitro at all ages studied (up to 12 months of age;[21]). In our study we were unable to detect any changes in LTP at CA1 synapses using two induction protocols (that employed respectively 40 and 400 stimuli). Of course, we cannot exclude the possibility 
that alterations in LTP may be observed with other patterns of activation or under different experimental conditions or in other pathways. Interestingly, a recent study has shown that deficits in LTP in vitro in mice overexpressing the Swedish mutant of APP are only seen if the animals are previously exposed to spatial training, not in naïve animals [40], suggesting that deficits in plasticity are subtle and subject to alterations based on prior experience. The primary conclusion, however, is that LTP is readily induced despite the pronounced and long-lasting increase in $A \beta(42)$ and $A \beta(40)$ levels in the hippocampus.

Alzheimer's disease is characterised by synaptic degeneration and changes in dendritic and axonal morphology [41-43]. Whilst these processes are not important for the earliest phase of LTP, they may become more important in the protein synthesis dependent phase of LTP. For this reason we extended our analysis of LTP beyond that which has been studied previously in slices obtained from transgenic models of Alzheimer's disease. However, we noticed little difference in LTP between the genotypes, even when followed for over $3 \mathrm{~h}$ post-induction. Theta patterns of activity are more physiological than tetanic stimulation and involve the activation of presynaptic $\mathrm{GABA}_{\mathrm{B}}$ receptors to transiently suppress GABA inhibition and thereby facilitate the activation of NMDA receptors [44]. Thus, LTP induced by theta patterns of activity may be more susceptible to regulatory influences, in particular those that affect GABA-mediated inhibition. In this context, we have previously observed that a deficit in LTP observed in APP null nice is normalised when $\mathrm{GABA}_{\mathrm{A}}$ receptor-mediated inhibition is blocked [45].

The finding that both basal synaptic transmission and LTP is normal in region CA1 of the hippocampus even when $A \beta$ levels are greatly enhanced and plaques are present may be considered somewhat surprising, particularly as the presence of plaques would be expected to disrupt the neuronal organisation of this region. However, these findings are consistent with some of the previous studies utilising transgenic mice relevant to AD. This would suggest that synaptic physiology remains normal in situations where $A \beta$ levels are elevated, at least in the CA1 region of the hippocampus. However, our experiments were performed without visualisation of plaques in the slices and thus we cannot rule out the possibility that the majority of our recording sites were in areas not containing plaques and that recording from regions neighbouring plaques may reveal a deficit in basal synaptic transmission and/or plasticity. This may also account for discrepancies between studies of transgenic mice expressing AD related proteins. Thus further experiments could target recordings from plaque containing regions. Ours and other studies investigating synaptic physiology from acutely prepared brain slices give an indication of transmission at individual or sets of syn- apses but do not provide information on the function of the hippocampus as a whole. If transmission and/or plasticity are impaired at only a fraction of the neurones in this structure then function (e.g. spatial learning) may be impaired.

Increasing evidence suggests that the form in which $A \beta$ is present in the brain is crucial in terms of whether neuronal function and memory is impaired. Thus oligomers rather than monomers or fibrils of $A \beta$ induce synapse loss and impair memory [46-48]. $\mathrm{A} \beta$ exists in the AD brain as a polydisperse mixture of high order oligomers and only these high molecular weight oligomers bind to hippocampal neurons [49]. Furthermore, cerebral injection of cell medium containing oligomers and monomers, but not fibrils, inhibits LTP in vivo [46]. As such the existence of $\mathrm{A} \beta$ oligomers rather then plaques may cause neuronal damage, and there is little correlation between the presence of plaques and severity of dementia in humans [50]. It may be, therefore, that although the mice used in the current study display $A \beta$ plaques, they do not produce an oligomeric form of $A \beta$ that is detrimental to neuronal health and function. Alternatively, it may be that a loss of normal APP function rather than an increase in A $\beta$ may cause an impairment in LTP, as APP knockout mice show deficits in LTP [45], and so differences in secreted APP between transgenic strains, which can have trophic and neuroprotective effects [51], may lead to differences in synaptic transmission and plasticity.

Another possibility for our finding, a lack of effect on LTP in the DbTg mice, is that other factors may be required for generating $\mathrm{AD}$-related impairments in hippocampal function, for example altered tau [52]. Consistent with this Roberson and colleagues have shown that reducing tau expression can affect amyloid related toxicity in transgenic mice without altering plaque deposition [53]. Human patients have additional pathology relative to transgenic mouse models utilising mutations in APP and PS1. In particular, although the mice show $A \beta$ plaques, they do not display intracellular tangles of hyperphosphorylated tau protein [54]. Oddo and colleagues [55] generated a triple transgenic mouse expressing mutated APP ( $\left.\mathrm{APP}_{\mathrm{SWE}}\right), \mathrm{PS} 1$ (M146V mutation) and tau (P301L mutation), which showed progressive development of both plaques and tangles as well as a reduction in hippocampal LTP. Such mice may represent a more robust model of AD.

\section{Conclusions}

In conclusion, it is clear from our present experiments that the cellular machinery for induction and expression of LTP at CA1 synapses is intact in these DbTg mice. This is apparent even in aged mice, which have been exposed to greatly elevated levels of $A \beta$ peptides for over 6 months. 


\section{Competing interests}

Frederick Kuenzi, Thomas Rosahl, David Smith, Huw Lewis and Guy Seabrook were employees of Merck Research Laboratories when this work was carried out. There are no other conflicts of interest.

\section{Authors' contributions}

Conceived and designed the experiments: SMF, FK, RAM, TWR, GRS, GLC Performed the experiments: FK, RAM, HL, DS, GRS

Analyzed the data: SMF, FK, RAM, GRS

Wrote the paper: SMF, FK, RAM, GRS, GLC.

\section{Acknowledgements}

We wish to thank David S. Reynolds for assistance in this project. The work was supported by a Medical Research Council (MRC) LINK award G9710681. The MRC was not involved in the design and conduct of the study, in the collection, analysis, and interpretation of the data, and in the preparation, review, or approval of the manuscript.

\section{Author Details}

'MRC Centre for Synaptic Plasticity, Department of Anatomy, University of Bristol, University Walk, Bristol, BS8 1TD, UK, ${ }^{2}$ The Neuroscience Research Centre, Merck Sharp and Dohme Research Laboratories, Terlings Park, Eastwick Road, Harlow, Essex, CM20 2QR, UK, ${ }^{3}$ Merck Research Laboratories, 126 E. Lincoln Ave, Rahway, NJ 07065, USA and ${ }^{4}$ Eli Lilly \& Company, Lilly Corporate Center, Indianapolis, Indiana 46285, USA

Received: 8 June 2010 Accepted: 14 July 2010

Published: 14 July 2010

\section{References}

1. Hardy J: Amyloid, the presenilins and Alzheimer's disease. Trends Neurosci 1997, 20(4):154-159.

2. Price DL, Sisodia SS: Mutant genes in familial Alzheimer's disease and transgenic models. Annu Rev Neurosci 1998, 21:479-505.

3. Newman M, Musgrave IF, Lardelli M: Alzheimer disease: amyloidogenesis, the presenilins and animal models. Biochimica et biophysica acta 2007, 1772(3):285-297.

4. Citron M, Oltersdorf T, Haass C, McConlogue L, Hung AY, Seubert P, VigoPelfrey C, Lieberburg I, Selkoe DJ: Mutation of the beta-amyloid precursor protein in familial Alzheimer's disease increases beta-protein production. Nature 1992, 360(6405):672-674.

5. Sherrington R, Rogaev El, Liang Y, Rogaeva EA, Levesque G, Ikeda M, Chi H, Lin C, Li G, Holman K, et al:: Cloning of a gene bearing missense mutations in early-onset familial Alzheimer's disease. Nature 1995, 375(6534):754-760.

6. Fraser PE, Yang DS, Yu G, Levesque L, Nishimura M, Arawaka S, Serpell LC, Rogaeva E, St George-Hyslop P: Presenilin structure, function and role in Alzheimer disease. Biochimica et biophysica acta 2000, 1502(1):1-15.

7. Citron M, Westaway D, Xia W, Carlson G, Diehl T, Levesque G, JohnsonWood K, Lee M, Seubert P, Davis A, et al:: Mutant presenilins of Alzheimer's disease increase production of 42-residue amyloid betaprotein in both transfected cells and transgenic mice. Nature medicine 1997, 3(1):67-72.

8. Zhang Z, Nadeau P, Song W, Donoviel D, Yuan M, Bernstein A, Yankner BA: Presenilins are required for gamma-secretase cleavage of beta-APP and transmembrane cleavage of Notch-1. Nat Cell Biol 2000, 2(7):463-465.

9. Hsiao K, Chapman P, Nilsen S, Eckman C, Harigaya Y, Younkin S, Yang F, Cole G: Correlative memory deficits, Abeta elevation, and amyloid plaques in transgenic mice. Science (New York, NY) 1996, 274(5284):99-102

10. Irizarry MC, McNamara M, Fedorchak K, Hsiao K, Hyman BT: APPSw transgenic mice develop age-related $A$ beta deposits and neuropil abnormalities, but no neuronal loss in CA1. JNeuropatholExpNeurol 1997, 56(9):965-973.

11. Frautschy SA, Yang F, Irrizarry M, Hyman B, Saido TC, Hsiao K, Cole GM: Microglial response to amyloid plaques in APPsw transgenic mice. Am J Pathol 1998, 152(1):307-317.

12. Chapman PF, White GL, Jones MW, Cooper-Blacketer D, Marshall VJ, Irizarry M, Younkin L, Good MA, Bliss TV, Hyman BT, et al.: Impaired synaptic plasticity and learning in aged amyloid precursor protein transgenic mice. Nature neuroscience 1999, 2(3):271-276.

13. Fitzjohn SM, Doherty AJ, Collingridge GL: The use of the hippocampal slice preparation in the study of Alzheimer's disease. European journal of pharmacology 2008, 585:50-59.

14. Fitzjohn SM, Morton RA, Kuenzi F, Rosahl TW, Shearman M, Lewis H, Smith D, Reynolds DS, Davies $\mathrm{CH}$, Collingridge GL, et al:: Age-related impairment of synaptic transmission but normal long-term potentiation in transgenic mice that overexpress the human APP695SWE mutant form of amyloid precursor protein. Journal of Neuroscience 2001, 21(13):4691-4698.

15. Brown JT, Richardson JC, Collingridge GL, Randall AD, Davies CH: Synaptic transmission and synchronous activity is disrupted in hippocampal slices taken from aged TAS10 mice. Hippocampus 2005, 15(1):110-117.

16. Parent A, Linden DJ, Sisodia SS, Borchelt DR: Synaptic transmission and hippocampal long-term potentiation in transgenic mice expressing FAD-linked presenilin 1. NeurobiolDis 1999, 6(1):56-62.

17. Borchelt DR, Thinakaran G, Eckman CB, Lee MK, Davenport F, Ratovitsky T, Prada CM, Kim G, Seekins S, Yager D, et al:: Familial Alzheimer's diseaselinked presenilin 1 variants elevate Abeta 1-42/1-40 ratio in vitro and in vivo. Neuron 1996, 17(5):1005-1013.

18. Duyckaerts C, Potier MC, Delatour B: Alzheimer disease models and human neuropathology: similarities and differences. Acta Neuropathol 2008, 115(1):5-38.

19. Trinchese F, Liu S, Battaglia F, Walter S, Mathews PM, Arancio O: Progressive age-related development of Alzheimer-like pathology in APP/PS1 mice. Annals of neurology 2004, 55(6):801-814.

20. Chang EH, Savage MJ, Flood DG, Thomas JM, Levy RB, Mahadomrongkul $V$, Shirao T, Aoki C, Huerta PT: AMPA receptor downscaling at the onset of Alzheimer's disease pathology in double knockin mice. Proceedings of the National Academy of Sciences of the United States of America 2006, 103(9):3410-3415

21. Volianskis A, Kostner R, Molgaard M, Hass S, Jensen MS: Episodic memory deficits are not related to altered glutamatergic synaptic transmission and plasticity in the CA1 hippocampus of the APPswe/PS1DeltaE9deleted transgenic mice model of beta-amyloidosis. Neurobiology of aging 2010, 31:1173-1187.

22. Hsiao KK, Borchelt DR, Olson K, Johannsdottir R, Kitt C, Yunis W, Xu S, Eckman C, Younkin S, Price D, et al:: Age-related CNS disorder and early death in transgenic FVB/N mice overexpressing Alzheimer amyloid precursor proteins. Neuron 1995, 15(5):1203-1218.

23. Qian $S$, Jiang $P$, Guan $X M$, Singh $G$, Trumbauer ME, Yu H, Chen HY, Van de Ploeg $\mathrm{LH}$, Zheng $\mathrm{H}$ : Mutant human presenilin 1 protects presenilin 1 null mouse against embryonic lethality and elevates Abeta 1-42/43 expression. Neuron 1998, 20(3):611-617.

24. Kuenzi F, Rosahl TW, Morton RA, Fitzjohn SM, Collingridge GL, Seabrook GR: Hippocampal synaptic plasticity in mice carrying the rd mutation in the gene encoding cGMP phosphodiesterase type 6 (PDE6). Brain Res 2003, 967(1-2):144-151.

25. Wimer RE, Wimer CC, Alameddine L, Cohen AJ: The mouse gene retinal degeneration $(\mathrm{rd})$ may reduce the number of neurons present in the adult hippocampal dentate gyrus. Brain research 1991, 547(2):275-278.

26. Lewis HD, Beher D, Smith D, Hewson L, Cookson N, Reynolds DS, Dawson GR, Jiang M, Van der Ploeg LH, Qian S, et al:: Novel aspects of accumulation dynamics and $\mathrm{A}$ beta composition in transgenic models of AD. Neurobiology of aging 2004, 25(9):1175-1185.

27. Priller $C$, Mitteregger $G$, Paluch $S$, Vassallo N, Staufenbiel M, Kretzschmar HA, Jucker M, Herms J: Excitatory synaptic transmission is depressed in cultured hippocampal neurons of APP/PS1 mice. Neurobiology of aging 2009, 30(8):1227-1237.

28. Moechars D, Dewachter I, Lorent K, Reverse D, Baekelandt V, Naidu A, Tesseur I, Spittaels K, Haute CV, Checler F, et al:: Early phenotypic changes in transgenic mice that overexpress different mutants of amyloid precursor protein in brain. JBiolChem 1999, 274(10):6483-6492.

29. Jacobsen JS, Wu CC, Redwine JM, Comery TA, Arias R, Bowlby M, Martone $\mathrm{R}$, Morrison $\mathrm{JH}$, Pangalos MN, Reinhart PH, et al: Early-onset behavioral and synaptic deficits in a mouse model of Alzheimer's disease. Proceedings of the National Academy of Sciences of the United States of America 2006, 103(13):5161-5166.

30. Games D, Adams D, Alessandrini R, Barbour R, Berthelette P, Blackwell C, Carr T, Clemens J, Donaldson T, Gillespie F: Alzheimer-type 
neuropathology in transgenic mice overexpressing V717F betaamyloid precursor protein. Nature 1995, 373(6514):523-527.

31. Hsia AY, Masliah E, McConlogue L, Yu GQ, Tatsuno G, Hu K, Kholodenko D, Malenka RC, Nicoll RA, Mucke L: Plaque-independent disruption of neural circuits in Alzheimer's disease mouse models. ProcNat/AcadSciUSA 1999, 96(6):3228-3233.

32. Larson J, Lynch G, Games D, Seubert P: Alterations in synaptic transmission and long-term potentiation in hippocampal slices from young and aged PDAPP mice. Brain Res 1999, 840(1-2):23-35.

33. Zaman SH, Parent A, Laskey A, Lee MK, Borchelt DR, Sisodia SS, Malinow R: Enhanced synaptic potentiation in transgenic mice expressing presenilin 1 familial Alzheimer's disease mutation is normalized with a benzodiazepine. Neurobio/Dis 2000, 7(1):54-63.

34. Morton RA, Kuenzi FM, Fitzjohn SM, Rosahl TW, Smith D, Zheng H, Shearman M, Collingridge GL, Seabrook GR: Impairment in hippocampal long-term potentiation in mice under-expressing the Alzheimer's disease related gene presenilin-1. NeurosciLett 2002, 319(1):37-40.

35. Yu H, Saura CA, Choi SY, Sun LD, Yang X, Handler M, Kawarabayashi T, Younkin L, Fedeles B, Wilson MA, et al:: APP processing and synaptic plasticity in presenilin-1 conditional knockout mice. Neuron 2001, 31(5):713-726

36. Gureviciene I, Ikonen S, Gurevicius K, Sarkaki A, van Groen T, Pussinen R, Ylinen A, Tanila H: Normal induction but accelerated decay of LTP in APP + PS1 transgenic mice. Neurobiology of disease 2004, 15(2):188-195.

37. Gruart A, Lopez-Ramos JC, Munoz MD, Delgado-Garcia JM: Aged wildtype and APP, PS1, and APP + PS1 mice present similar deficits in associative learning and synaptic plasticity independent of amyloid load. Neurobiology of disease 2008, 30(3):439-450.

38. Park SW, Ko HG, Lee N, Lee HR, Rim YS, Kim H, Lee K, Kaang BK: Aged wildtype littermates and APPswe+PS1/ $\triangle \mathrm{E} 9$ mice present similar deficits in associative learning and spatial memory independent of amyloid load. Genes \& Genomics 2010, 32:63-70.

39. Gengler S, Hamilton A, Holscher C: Synaptic plasticity in the hippocampus of a APP/PS1 mouse model of Alzheimer's disease is impaired in old but not young mice. PLOS ONE 5(3):e9764.

40. Middei S, Roberto A, Berretta N, Panico MB, Lista S, Bernardi G, Mercuri NB, Ammassari-Teule M, Nistico R: Learning discloses abnormal structural and functional plasticity at hippocampal synapses in the APP23 mouse model of Alzheimer's disease. Learning \& memory (Cold Spring Harbor, NY 2010, 17(5):236-240

41. Knowles RB, Wyart C, Buldyrev SV, Cruz L, Urbanc B, Hasselmo ME, Stanley HE, Hyman BT: Plaque-induced neurite abnormalities: implications for disruption of neural networks in Alzheimer's disease. Proceedings of the National Academy of Sciences of the United States of America 1999, 96(9):5274-5279.

42. Phinney AL, Deller T, Stalder M, Calhoun ME, Frotscher M, Sommer B, Staufenbiel M, Jucker M: Cerebral amyloid induces aberrant axonal sprouting and ectopic terminal formation in amyloid precursor protein transgenic mice. J Neurosci 1999, 19(19):8552-8559.

43. Arendt T: Alzheimer's disease as a disorder of mechanisms underlying structural brain self-organization. Neuroscience 2001, 102(4):723-765.

44. Davies $\mathrm{CH}$, Collingridge $\mathrm{GL}$ : The physiological regulation of synaptic inhibition by GABAB autoreceptors in rat hippocampus. Journal of Physiology 1993, 472:245-265.

45. Fitzjohn SM, Morton RA, Kuenzi F, Davies CH, Seabrook GR, Collingridge GL: Similar levels of long-term potentiation in amyloid precursor protein -null and wild-type mice in the CA1 region of picrotoxin treated slices. Neuroscience letters 2000, 288(1):9-12.

46. Walsh DM, Klyubin I, Fadeeva JV, Cullen WK, Anwyl R, Wolfe MS, Rowan MJ, Selkoe DJ: Naturally secreted oligomers of amyloid beta protein potently inhibit hippocampal long-term potentiation in vivo. Nature 2002, 416(6880):535-539.

47. Lesne S, Koh MT, Kotilinek L, Kayed R, Glabe CG, Yang A, Gallagher M, Ashe $\mathrm{KH}$ : A specific amyloid-beta protein assembly in the brain impairs memory. Nature 2006, 440(7082):352-357.

48. Shankar GM, Bloodgood BL, Townsend M, Walsh DM, Selkoe DJ, Sabatini BL: Natural oligomers of the Alzheimer amyloid-beta protein induce reversible synapse loss by modulating an NMDA-type glutamate receptor-dependent signaling pathway. J Neurosci 2007, 27(11):2866-2875

49. Hepler RW, Grimm KM, Nahas DD, Breese R, Dodson EC, Acton P, Kelle PM, Yeager M, Wang H, Shughrue P, et al.: Solution state characterization of amyloid beta-derived diffusible ligands. Biochemistry 2006, 45(51):15157-15167.

50. Terry RD, Masliah E, Salmon DP, Butters N, DeTeresa R, Hill R, Hansen LA, Katzman R: Physical basis of cognitive alterations in Alzheimer's disease: synapse loss is the major correlate of cognitive impairment. Annals of neurology 1991, 30(4):572-580.

51. Goodman Y, Mattson MP: Secreted forms of beta-amyloid precurso protein protect hippocampal neurons against amyloid beta-peptideinduced oxidative injury. Experimental neurology 1994, 128(1):1-12.

52. Seabrook GR, Ray WJ, Shearman M, Hutton M: Beyond amyloid: the next generation of Alzheimer's disease therapeutics. Mol Interv 2007, 7(5):261-270.

53. Roberson ED, Scearce-Levie K, Palop JJ, Yan F, Cheng IH, Wu T, Gerstein H, Yu GQ, Mucke L: Reducing endogenous tau ameliorates amyloid betainduced deficits in an Alzheimer's disease mouse model. Science (New York, NY) 2007, 316(5825):750-754

54. Ashe KH: Mechanisms of memory loss in Abeta and tau mouse models. Biochem Soc Trans 2005, 33(Pt 4):591-594.

55. Oddo S, Caccamo A, Shepherd JD, Murphy MP, Golde TE, Kayed R, Metherate R, Mattson MP, Akbari Y, LaFerla FM: Triple-transgenic model of Alzheimer's disease with plaques and tangles: intracellular Abeta and synaptic dysfunction. Neuron 2003, 39(3):409-421.

\section{doi: $10.1186 / 1756-6606-3-21$}

Cite this article as: Fitzjohn et al., A study of long-term potentiation in transgenic mice over-expressing mutant forms of both amyloid precursor protein and presenilin-1 Molecular Brain 2010, 3:21

\section{Submit your next manuscript to BioMed Central and take full advantage of:}

- Convenient online submission

- Thorough peer review

- No space constraints or color figure charges

- Immediate publication on acceptance

- Inclusion in PubMed, CAS, Scopus and Google Scholar

- Research which is freely available for redistribution
C) BioMed Central 